\title{
TO THE VALIDATION OF SOME SYNTAXA OF THE LOISELEURIO-VACCINIETEA FROM THE WESTERN CARPATHIANS PUBLISHED IN HACQUETIA 2006, 5/1: 37-71
}

\author{
Jozef ŠIBÍK ${ }^{1}$, Ján KLIMENT ${ }^{2}$, Ivan JAROLÍMEK ${ }^{1}$, Zuzana DÚBRAVCOVÁ, \\ Radmila BĚLOHLÁVKOVÁ ${ }^{4} \&$ Libuše PACLOVÁ ${ }^{5}$
}

In this note, we would like to correct some nomenclatural inexactitudes published in the article by Šisík et al. (2006).

The two association names - Cetrario nivalis- $\mathrm{Va}$ cinietum gaultherioidis and Junco trifidi-Callunetum vulgaris of Sibík et al. (2006) were published without being indicated expressis verbis as new (nomen novum - nom. nov.), hence, their announcement is invalid according to article $3 \mathrm{i}$ of the International Code of Phytosociological Nomenclature (ICPN, Weber et al. 2000). Therefore, we have made the correction and validated them following art. 6 of the ICPN.

Cetrario nivalis-Vaccinietum gaultherioidis (Hadač 1956) Hadač ex Šibík et al. nom. nov. hoc loco

Basionym: Cetrario-Vaccinietum uliginosum tatricum Hadač 1956 (art. 34a)

Synonyms: Cetrario nivalis-Vaccinietum gaultherioidis Hadač (1956) 1987 (art. 2b), Cetrario nivalis-Vaccinietum gaultherioidis (Hadač 1956) Hadač ex Šibík et al. 2006 (art. 3i)

Nomenclatural type: Hadač 1956, tab. 6, r. 40, lectotypus Šibík et al. (2006: 40)

Although „Cetraria nivalis“ is not present in the original Hadač table (Hadač 1956, Tab. 6), we consider the occurrence of "Cladonia nivalis“ in relevé
40 of table 6 as sufficient for the selection of „Cetraria nivalis" as the name-giving taxon. Cladonia nivalis mentioned by Hadač (l. c.) in the association Cetrario-Vaccinietum uliginosi tatricum (p. 25) is not an existing lichen species. This name is just a misprint; the correct one is Cetraria nivalis. Thus, using „Cetraria nivalis" in the association name proposed by Hadač (1987: 9) is an indirect correction of Hadač's (Hadač 1956: 26) misprint.

In spite of the fact that Cetraria nivalis occurred only rarely in Hadač's table (Hadač 1956), we suppose that when the author suggested the new name - the Cetrario nivalis-Vaccinietum gaultherioidis (Hadač 1987: 9) - he was drawing on his rich experience with this type of communities, and on the fact that this species well indicated windward and inhospitable habitats.

Junco trifidi-Callunetum vulgaris (Krajina 1933) Hadač ex Sibík et al. nom. nov. hoc loco

Basionym: Callunetum vulgaris tatricum Krajina 1933 (art. 34a)

Synonyms: Junco trifidi-Callunetum (Krajina 1933) Hadač 1987 (art. 2b), Junco trifidi-Callunetum vulgaris (Krajina 1933) Hadač ex Šibík et al. 2006 (art. 3i) Nomenclatural type: Krajina 1933, tab. 51, r. 4, lectotypus Šibík et al. (2006: 42)

\footnotetext{
${ }^{1}$ Institute of Botany, Slovak Academy of Sciences, Dúbravská cesta 14, SK-845 23 Bratislava, Slovak Republic, e-mail: ivan.jarolimek@savba.sk,jozef.sibik@savba.sk

${ }^{2}$ Botanical Garden of Comenius University, SK-038 15 Blatnica, Slovak Republic, e-mail: kliment@rec.uniba.sk

${ }^{3}$ Department of Botany, Faculty of Natural Sciences, Comenius University, Révová 39, SK-811 02 Bratislava, Slovak Republic, e-mail: dubravcova@fns.uniba.sk

${ }^{4}$ Institute of Botany, Academy of Sciences of the Czech Republic, CZ-252 43 Průhonice, Czech Republic, e-mail:

belohlavkova@ibot.cas.cz

${ }^{5}$ Červená Řečice no. 341, CZ-394 46, Czech Republic, e-mail: jpacl@sendme.cz
} 
Vaccinion myrtilli Krajina 1933

Nomenclatural type: Vaccinietum myrtilli tatricum Szafer et al. 1927, lectotypus hoc loco

Krajina (1933) assigned the authorship of the association's Vaccinietum myrtilli tatricum description to Szafer et al. (1927). Forasmuch as the subassociation Vaccinietum myrtilli tatricum subalpinum Krajina 1933 is subordinate to the latter association, according to art. 20 of the ICPN (Weber et al. 2000 ) only this syntaxon [not the subassociation, as it was done by Šibík et al. (2006: 43)] has to be chosen as the nomenclatural type. Therefore, we have repeatedly lectotypified the alliance with the Vaccinietum myrtilli tatricum Szafer et al. 1927.

Avenastro versicoloris-Vaccinietum myrtilli Krajina 1933 nom. invers. propos.

Nomenclatural type: Krajina 1933: tab. 52, r. 1, lectotypus Unar et al. (1985: 24)

Although, the association Myrtilleto-Avenastretum versicoloris Krajina 1933 sensu Unar et al. (1984, $1985)$ is more similar to siliceous grasslands of the alliance Juncion trifidi (see Šibík et al. 2006: 46), the lectotype which has been chosen by Unar et al. (1985: 24) has a priority over the one proposed by Sibík et al. (2006: 45). The new lectotypification is then superfluous.

Acknowledgements. The authors are grateful to Jean-Paul Theurillat who noticed that some new syntaxa names were published in our previous article invalidly; and to the editorial board of Hacquetia for allowing us to publish these corrections.

\section{REFERENCES}

Hadač, E. 1956: Rostlinná společenstva Temnosmrečinové doliny ve Vysokých Tatrách. Biol. Práce Slov. Akad. Vied 2/1: 1-78.

Hadač, E. 1987: Plant ecological notes from the Belianske Tatry Mts. Biol. Práce Slov. Akad. Vied 23(3): 1-96.

Krajina, V. 1933: Die Pflanzengesellschaften des Mlynica-Tales in den Vysoké Tatry (Hohe Tatra). 2. Teil. Beih. Bot. Centralbl. 51: 1-224.

Szafer, W., Pawłowski, B. \& Kulczyński, S. 1927: Die Pflanzenassoziationen des Tatra-Gebirges. III. Teil: Die Pflanzenassoziationen des KościeliskaTales. Bull. Int. Acad. Polon. Sci., Cl. Sci. Math., Ser. B, Sci. Nath., Suppl 2 (1926): 13-78.

Šibík, J., Kliment, J., Jarolímek, I., Dúbravcová, Z., Bělohlávková, R. \& Paclová, L. 2006: Syntaxonomy and nomenclature of the alpine heaths (the class Loiseleurio-Vaccinietea) in the Western Carpathians. - Hacquetia, Ljubljana, 5/1: 37-71.

Unar, J., Unarová, M. \& Šmarda, J. 1984: Vegetační poměry Tomanovy doliny a Žlebu spod Diery v Západních Tatrách. 1. Fytocenologické tabulky. Folia Fac. Sci. Nat. Univ. Purkynianae Brun., Ser. Biol. 25/10: 5-101.

Unar, J., Unarová, M. \& Šmarda, J. 1985: Vegetační poměry Tomanovy doliny a Žlebu spod Diery v Západních Tatrách. 2. Charakteristika přírodních poměrů a rostlinných společenstev. Folia Fac. Sci. Nat. Univ. Purkynianae Brun., Ser. Biol. 26/14: 5-78.

Weber, H. E., Moravec, J. \& Theurillat, J.-P. 2000: International Code of Phytosociological Nomenclature. Ed. 3. J. Veget. Sci. 11: 739-768. 